\title{
INFRASTRUCTURAL COMPONENT OF INVESTMENT-INNOVATIVE DEVELOPMENT IN SMALL BUSINESS (BY THE EXAMPLE OF BELGOROD REGION'S AGRICULTURAL COMPLEX)
}

\author{
Yuri Anatolievich Doroshenko* \\ Belgorod State Technological University named after V.G. Shukhov, Russia \\ Aleksandr Sergeevich Troshin \\ Belgorod State Technological University named after V.G. Shukhov, Russia \\ Elena Nikolaevna Chizhova \\ Belgorod State Technological University named after V.G. Shukhov, Russia \\ Irina Vladimirovna Somina \\ Belgorod State Technological University named after V.G. Shukhov, Russia \\ Irina Sergeevna Pivko \\ Belgorod State Technological University named after V.G. Shukhov, Russia
}

Conducted an analysis of such possibility as establishment of infrastructure elements of small busines's investment-innovative development as regional centers of agricultural technologies transfer (RCATT) and venture funds. Basic strategic purposes and principles of RCATT in context of small enterpreneurship were formulated. Technological segments and possible instruments of interaction between small entrepreneurship and RCATT were stated. Practical experience of private public partnership implementation in Russia and abroad was analyzed. The role of venture fund in development of small entrepreneurship was determined and represented in form of investment declaration. The scheme of venture investment implementation with participation (based on materials of Belgorod region) of small business was presented. Individually the key steps of innovation process in small business were analyzed.

Key words: Belgorod region, Agricultural complex, Small business, Private public partnership, Venture fund, Innovative process, Regional center of agricultural technologies transfer, Technological segments, Economic mechannism, Innovations, Investment, Localisation, Licensing

\section{INTRODUCTION}

Level of Russia's economic development in general and its small business depend on degree of investment activity of its structure units at macro-, meso- and micro levels. Innovation activity is a dominant area of investment in modern conditions of postindustrial economy [01 - 04]. Such tendency has a global scope and touches not only developed countries, but also countries with transitional economy and developing countries. Beginning of world innovative model is being observed. Inevitability of that process is dictated by activation of globalisation process and integration of leading countries economies. It is necessary for Russia, as fast as possible, to implement a transformation of its innovative potential in accordance with changing conditions of external environment in purposes of development activation of elements which compound it. The leading role in that process has to be taken by government through creation of favourable investment-innovative conditions for small and medium-sized businesses, investors and involvement of foreign investment into country's economy. One of issues that have to be quickly solved is establishment of appropriate regulatory legal foundation for investment in innovative activity in small entrepreneeuship area.

It is still an actual question of optimization of investment portfolio of small and medium business in country's agricultural complex (AC), which can be explained by existing features and that role, which investment play for it. 


\section{METHODOLOGY}

Investment issues of innovative activity in small business have been being studying subject of leading scientists and specialists for a long time. A significant contribution in development of scientific approaches in investment area was made by many Russian and foreign researches: S.A. Agarkov, V.Z. Mazloev, I.S. Sandu, I.G. Ushachev, U.F. Sharp and others [05, 06, 07, 08, 09].

Questions of theory and methodology of investment in innovative activity, including amsll and medium business, found its reflection in scientific papers of economists: L.I. Abalkin, Y.A. Doroshenko, V.V. Kuznetsov, Y.S. Melkumov, V.I. Nechaev and others [10, 11, 12, 13, 14, and 15].

There is an essential necessity in forming of regional organization-economic mechanisms of investment in innovations, directed at solving the issues of agricultural technologies transfer and utilization of public private partnership mechanisms for implementation of venture investment in small entrepreneurship.

\section{MAIN PART}

By analyzing of innovative system as a one of components of economic mechanism, inside of it we should notice a specific set of structural elements of lower hierarchy, which are being interconnected, by other words, some sort of investment-innovative infrastructure, which provides creation of innovations in small and medium businesses, and, more importantly, theiir trannsfer. Such mechanism could find its reflection within forming of regional centers of agricultural technologies transfer (RCATT, with reference to AC), which have to become a part of existent regional innovative systems after the restructurization.

Model of RCATT presented in that paperwork consolidates functions of innovation promotion and, from scieentific point of view, is a part of innovative subsystem of integrated economic mechanism. As initial strategic purpposes of being-made regional center of agricultural technologies transfer in context of development of small entrepreneurship we can consider the following:

- assistance to technological growth through growth of labour productivity, identification of demand for new technologies, supporting of processes of their transfer and localisation;

- making of preconditions for commercialisation of new technologies for shaping of necessary set of instruments for support of scientific researches and possibility of their further transfer;

- assistance to regional economic growth, which can be achieved, from one side, through creation of effective business models, from the other side - through obtaining of economic profit from activity.

- Main task of regional center of agriculture technologies transfer is promotion of Russian and foreign innovative technologies into entrepreneurial environment through state structure.

- An activity of RCATT (with reference to entrepreneurship in AC)must be based upon the following principles:

- identification and focusing of the most potentially favourable (by row of criterias) technological segments of small business. To such segments can be related the following industries: poultry faming, pig-breeding, dairy husbanndry;

- optimization of instruments for technologies transfer portfolio. Among them there are localisation of high-tech domestic and foreign technologies, protection of intellectual property (IP) and licensing, provision of professional informational-consulting services.

The process of localisation of domestic and foreign agricultural technologies was analyzed from point of view of core phases of investment projects life cycle (Table 1).

Economic purpose of utilization of such instrument as localisation consists in decreasing of investment risk level, a significant decreasing of lag in final product outcome, growth in quantity of sucessful projects.

A certain attention must be paid too establishment of development center of high-agricultural technologies, which activity will be consisted from integration of efforts of technology owner, regional scientific institutions and investors.

Licensing and transfer of patents are not functionally complex instruments and have a wide usage in Russia as much as in the world.

It can be the following action scheme:

- forcing for innovations at regional level (government's initiative);

- establishment of new technological decisions by R\&D organizations. Protection 
of intellectual property in Regional center of agricultural technologies transfer;

- searching of potential contractors - consumers of agricultural technologies;
- implementation of agricultural technologies in agricultural sector of economy;

- gaining of royalty payment;

- payment of royalty to R\&D organizations.

Table 1: Stages of agricultural technologies localisation process

\begin{tabular}{|c|c|c|c|c|}
\hline \multirow{3}{*}{$\begin{array}{l}\stackrel{0}{\pi} \\
\stackrel{\pi}{\omega}\end{array}$} & \multicolumn{4}{|c|}{ Phase of project's life cycle } \\
\hline & Preinvestment & & estment & Exploitation \\
\hline & Observation & Adaptation & Integration & Exploitation \\
\hline 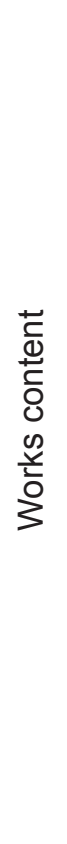 & $\begin{array}{ll}\text { 1. } & \text { Evaluation of } \\
\text { exist } \\
\text { agricultural } \\
\text { technologies. } \\
\text { 2. Evaluation of } \\
\text { tendencies in } \\
\text { area of } \\
\text { technological } \\
\text { decisions } \\
\text { implementation. } \\
\text { 3. Identification } \\
\text { and evaluation } \\
\text { of target } \\
\text { agricultural } \\
\text { technologies. } \\
\text { 4. Search of } \\
\text { potential } \\
\text { contractors. }\end{array}$ & $\begin{array}{l}\text { 1. Modification of } \\
\text { technological } \\
\text { decision for } \\
\text { preparadness } \\
\text { to implement } \\
\text { with support of } \\
\text { RCATT } \\
\text { 2. Continuation of } \\
\text { interaction with } \\
\text { potential } \\
\text { contractor - con- } \\
\text { sumer of agricul- } \\
\text { tural technology. } \\
\text { 3. Support of high- } \\
\text { technologies } \\
\text { development } \\
\text { center. }\end{array}$ & $\begin{array}{l}\text { 1. Practical inplementa- } \\
\text { tion of approved tech- } \\
\text { nological solutions into } \\
\text { production process. } \\
\text { 2. Support of high-tech- } \\
\text { nologies development } \\
\text { center }\end{array}$ & $\begin{array}{l}\text { 1. The complete trans- } \\
\text { fer of know-how to } \\
\text { contractor - con- } \\
\text { sumer of agricultural } \\
\text { technology. } \\
\text { 2. Transfer of knowledg- } \\
\text { es about manage- } \\
\text { ment and servicing of } \\
\text { obtained agriculture } \\
\text { technology. } \\
\text { 3. Participation of } \\
\text { regional center of ag- } \\
\text { ricultural technologies } \\
\text { transfer in process of } \\
\text { possible moderniza- } \\
\text { tion of agricultural } \\
\text { technology (if neces- } \\
\text { sary). } \\
\text { 4. Support of high-tech- } \\
\text { nologies } \\
\text { development center. }\end{array}$ \\
\hline 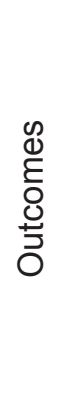 & $\begin{array}{l}\text { 1. Identification of } \\
\text { target agricultur- } \\
\text { al technology. } \\
\text { 2. Identification of } \\
\text { potential con- } \\
\text { tractor-consum- } \\
\text { er of agricultural } \\
\text { technology. }\end{array}$ & $\begin{array}{l}\text { 1. Preparadness } \\
\text { of technological } \\
\text { solution for imple- } \\
\text { mentation. } \\
\text { 2. Accordance of } \\
\text { potential contrac- } \\
\text { tor-consumer for } \\
\text { implementation of } \\
\text { chosen techno- } \\
\text { logical decision. }\end{array}$ & $\begin{array}{l}\text { 1. Technology has been } \\
\text { implemented. } \\
\text { 2. Trial launching of } \\
\text { agricultural technology } \\
\text { with support of region- } \\
\text { al center of agricultural } \\
\text { technologies transfer }\end{array}$ & \begin{tabular}{|l} 
1. Exploitation of \\
agricultural \\
technology without \\
support from RCATT. \\
2. Self-maintained sup- \\
port of agricultural \\
technology by \\
contractor - consum- \\
er of technology.
\end{tabular} \\
\hline
\end{tabular}

Provision of professional informative-consulting services for small business consists in conduction of contract-based researches, education, consultancy and expert support.

Activities of RCATT will also support a search of potential contractors and coordination of work within conducting of contract-based researches. In that case it is possible to use such instrument as outsourcing.

- identification of key instruments within frame of chosen technological segmennts (Figure 1).

- step by step development of selected technological segments;
- an effective organization of regional center of agricultural technologies transfer, which will promote an achievement of planned results in a process of implementation of strategic purposes and selected development destinations.

Characteristic of activity of proposed RCATT for purposes of small business represented in table 2. In this connection it is necessary to take into account that effective organization of regional center of agricultural technologies transfer will promote an achievement of planned results only through the process of strategic purposes and selected development directions. 


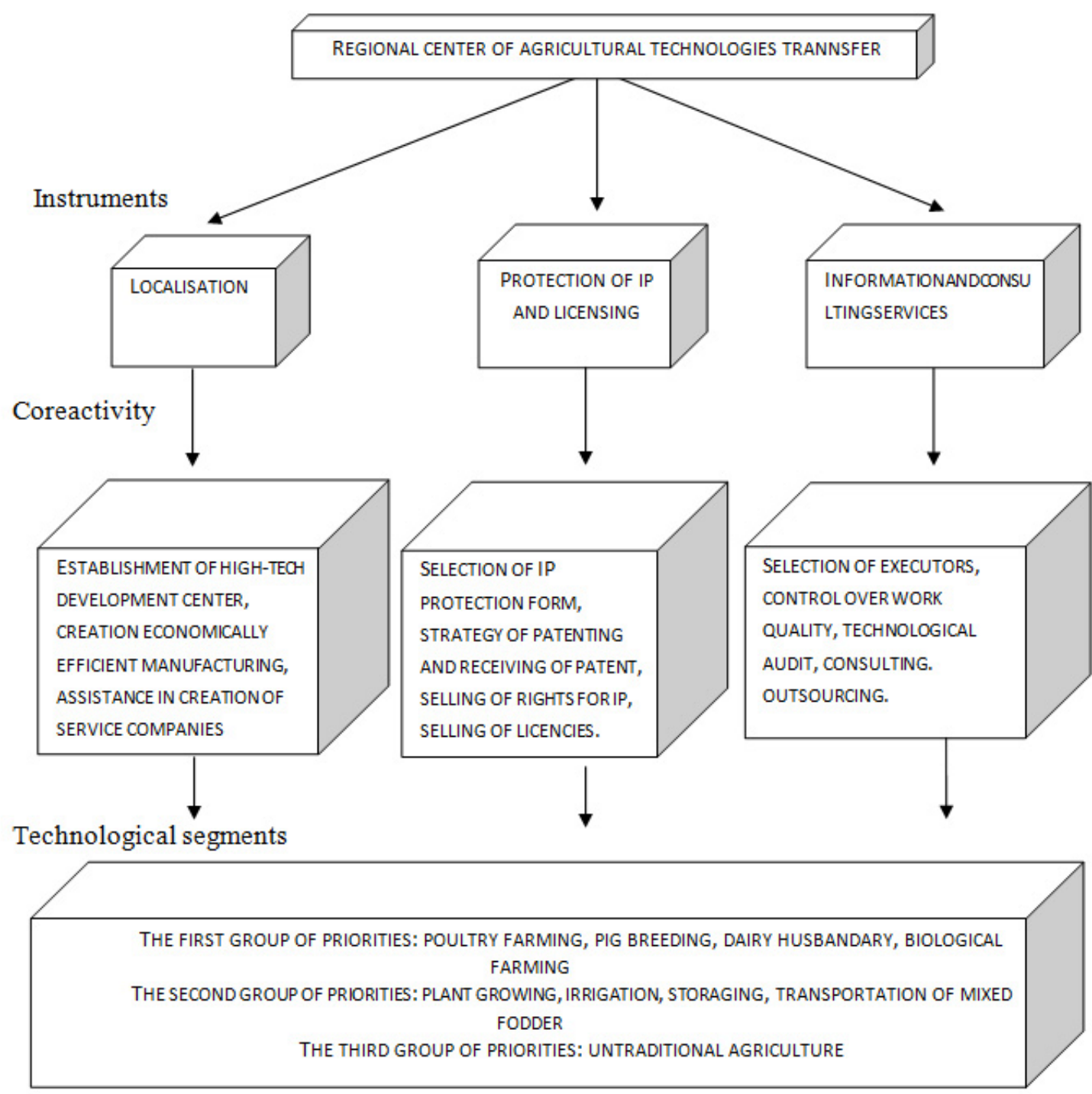

Figure 1: Technological segments of interaction between small entrepreneurship and RCATT

Solving of task to follow tha innovative way of development for Russia's economy is been seen to be highly problematic without utilization of modern instruments and mechanisms, a special place among which belongs to public private partnership (PPP). RAS's Institute of Economy defines PPP as «institutional and organizational alliance of state authority and private business with purpose of implementation of socially important projects in wide range of areas - from development of strategically significant economic industries to provision of social services within the country's scope and separate territories».

OECD Scientific and Technological Policy Committee, defining the term of PPP, determines its following chharacteristics:

- partnership must represent alliance between governmental and private sectors of economy;
- partner relationships must have a documentary approvement;

- partner relationships have to be grounded on equal basis;

- it is necessary to have mutual purposes with marked governmental interest;

- accomplishment of stated purposes has to be based on unification of partnership's participants' inputs;

- members of partnership have not only to distribute investment expences and project's risks between themselves, but also to jointly participate in usage of achieved results. 
Table 2: Instruments of interaction between RCATT and small entrepreneurship

\begin{tabular}{|l|l|l|l|}
\hline Instruments & \multicolumn{1}{|c|}{2015} & \multicolumn{1}{|c|}{2020} & \multicolumn{1}{c|}{2025} \\
\hline Localisation & $\begin{array}{l}\text { Practical implementation } \\
\text { of localisation instruments, } \\
\text { conduction of marketing } \\
\text { researches. }\end{array}$ & $\begin{array}{l}\text { Transfer to serial manufactur- } \\
\text { ing based on certain tech- } \\
\text { nological solution, maximum } \\
\text { integration of participants } \\
\text { within support of projects of } \\
\text { high-tech development center. }\end{array}$ & $\begin{array}{l}\text { Development of export of } \\
\text { technological solutions, } \\
\text { broadening of activity be- } \\
\text { yond limits of RCATT. }\end{array}$ \\
\hline $\begin{array}{l}\text { Protection of IP } \\
\text { and licencing }\end{array}$ & $\begin{array}{l}\text { Concentration of efforts on } \\
\text { coordination of operations } \\
\text { with R\&D organizations, } \\
\text { building up a reputation. }\end{array}$ & $\begin{array}{l}\text { Expanding of activity scope, } \\
\text { focusing on marketing, imple- } \\
\text { mentation of strategy of out- } \\
\text { come at international market. }\end{array}$ & $\begin{array}{l}\text { Key direction of profes- } \\
\text { sional activity of RCATT }\end{array}$ \\
\hline Informative-con- \\
sulting services
\end{tabular}

V.G. Varnavsky determines PPP as «institutional and organizational alliance between government and business in purpose of implementation of significantly important social projects and programs in wide range of industries and R\&D, including non-manufacturing business».

In general, definition of PPP reflects long-term, mutually settled relationships of state and private business, to which we can say yes.

The subject of specific discussions can be only an issue of definition of industrial structure for practical utilization of current mechanism. In this way, if RAS'S Institute of Economy does not identify a specific list of industries for possible application of PPP, then in definition of V.G. Varnavsky among such industries has been analyzed, firstly, manufacturing and services, which, in our point of view, not fully acceptable.

The mechanisms of PPP have to possess a firstpriority possibility to be implmented in accordance with prior directions of Russia's economic development, among which agriculture holds not the last place.

From countries with significant results of PPP implmentation, including small business area, we can mark out Great Britain, USA, Germany, France, Italy, Japan, Israel;

- transport infrastructure: Australia, Austria, Belgium, Great Britain, Germany, Spain, China, Canada, USA;

- water supplement: Great Britain, Belgium, Germany, India, Spain, China, USA, France;

- wastes reprocessing and environment protection: Belgium, Great Britain, Canada, China, France;
- energy: China, France, Japan;

- healthcare: Belgium, Great Britain, Israel, Spain, France;

- education: Great Britain, Ireland;

- culture: Great Britain, Japan;

- penal system: Great Britain, Canada, USA, Japan;

- innovative activity: Great Britain, Germany, Netherlands, Israel, China, USA, France, Sweden.

Innovative activity, as a subject of interest for PPP programs, is typical for absolute majority of developed countries. Basic principles of PPP typical for most countries are being taken down to role of state, which lays in promotion of fundamental science development, establishment of necessary infrastructure and favourable investment climate, which is essentialy important. Small and mediumsized businesses in such situation take functions of creation of innovative technologies, their transfer and commercialization.

The key problems of implementation of innovative projects based on PPP approach in small and medium business in our country connect wiith underdevelopment of PPP instruments, including:

- low efficiency of current institutional system of PPP support and authority bodies;

- lack of development of concessions practice for implementation of innovative projects within PPP;

- non-systematical approach to financial-economic interaction between state and small business in a process of implementation of 
innovative projects with utilization of PPP mechanism;

- underdevelopment of regulatory-legal basis of risks and responsibilities distribution within PPP in innovative sphere of small business;

- support of manufactured export;

- stimulating and development of venture

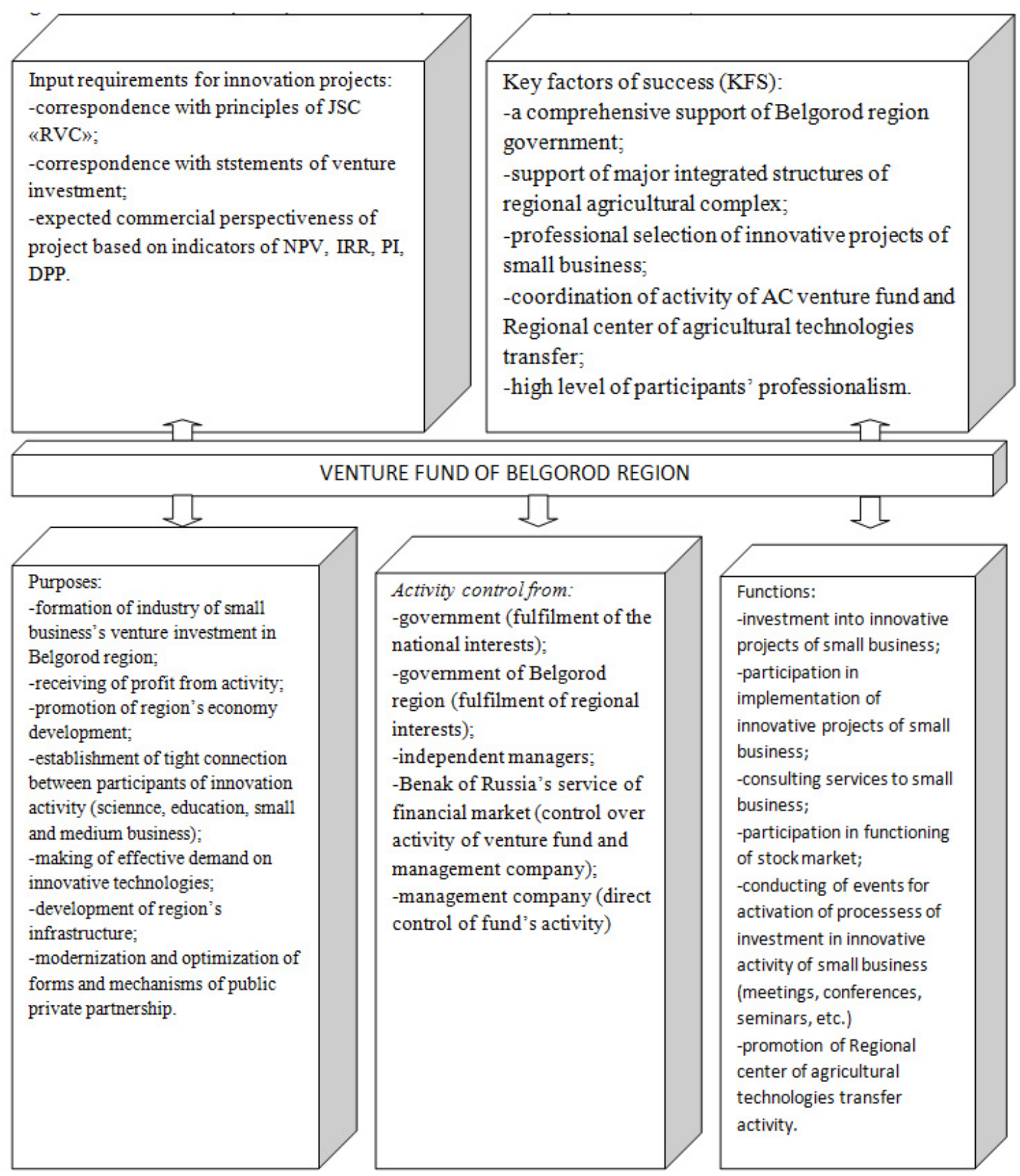

Figure 2: Role of venture fund in development of small entrepreneurship in Belgorod region

At regional level (on exmaple of Belgorod region) mechanisms of PPP can be implemented within creation of venture fund in $A C$, which is explainable, considering the level of its development and presence of competetive producers of

\section{financing and processes of technologies} commercialization;

In agricultural complex the relations between state and small and medium business are fixed in shape of joint ventures, agricultural holdings, clusters (innovative and territorial-manufacturing), indutrsial unions, agricultural technical parks, R\&D centers, scientifically-productive systems and etc.
Key factors of success (KFS)

-a comprehensive support of Belgorod region government;

-coordination of activity of AC venture fund and Regional center of agricultural technologies transfer;

-high level of participants' professionalism 
novative structures (decree of Government of Russian Federation from the $7^{\text {th }}$ of June 2006 № 838-p). Establishment of venture fund in agricultural sector of Belgorod region, in our opinion, might become a catalyst of innovative activity of the whole entrepreneurship. We proposed to establish a venture fund in a form of ended mutual fund. Basic purposes and functions of fund are represented at Figure 2. Investment declaration of venture funds in part of small entrepreneurship development has to be based upon the following statements:

- a special-purpose character of investment (investment only into innovative company of small business);

- dependance of investment amounts on stage of innovative company's development (minimum of $80 \%$ assets have to be invested into small business innovative companies at early stage of development);

- principle of investment diversification (per 5 years at least 8 innovative companies from small business have to be objects of investment);

- limitations of investment areas (investment prohibition for traditional economic industries and the ones which do not meet regulatory-legal requirements);

- limitation of aggregate compensation to members of venture fund (management company, specialized depositary, registrar of investment share owners, auditor, appraisor in aggregate can pretend for compensation within $2.5 \%$ of fund's assets cost).

Possible scheme of venture investment implementation with participation of small business represented at Figure 3.

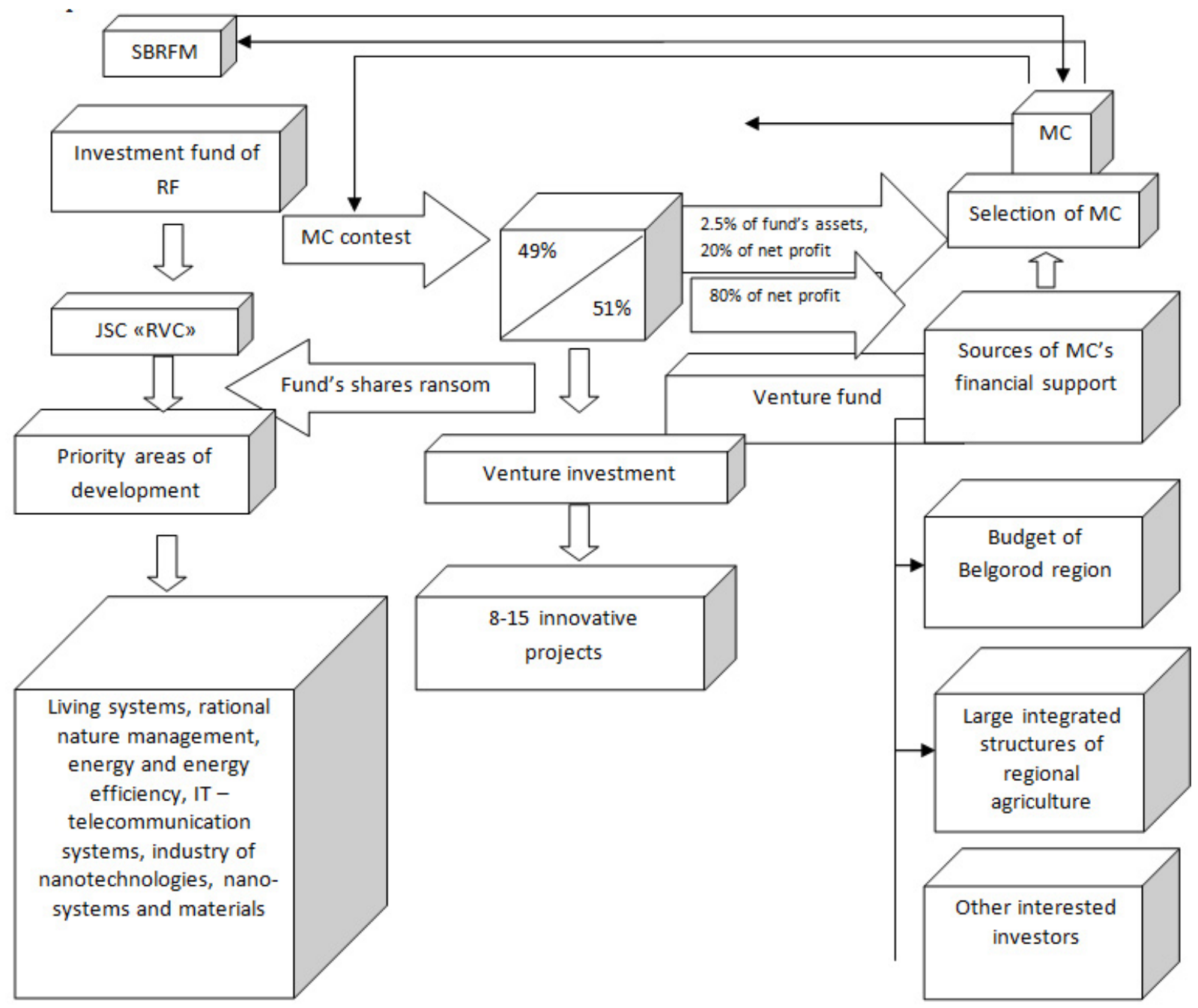

Figure 3: Scheme of venture investment process with participation of small business (based on materials of Belgorod region) 
The forecast average level of fund's revenue will be from30 to $40 \%$ annually. Management company's (MC) concernmment in functioning of establishing funds will be stipulated by, firstly, annually sum of compensation, calculated on basis of fund's assets cost (but not more than $2.5 \%$ ), and secondly, by fund's net profit (approximately $20 \%$, which is acceptablee in world practice).

Comment: SBRFM - Sberbank of Russia's ser- vice of Financial Market, MC - management company, JSC «RVC» - JSC «Russian venture company". Possible structural representation of core phases of innovative processes with utilization of public private partnership in small entrepreneurship during implementation of venture investment (according to classification of European association of venture investment) is represented in Table 3.

Table 3: Characteristic of core stages of innovative process in small entrepreneurship

\begin{tabular}{|c|c|c|c|}
\hline $\begin{array}{c}\text { STAGE OF INNOVATIVE } \\
\text { PROCESS }\end{array}$ & Characteristic & Source of financing & $\begin{array}{c}\text { Number of } \\
\text { projects } \\
\text { successfully passed } \\
\text { the stage, } \% \\
\end{array}$ \\
\hline Seed - stage & $\begin{array}{c}\text { CREATION OF BUSINESS } \\
\text { IDEA }\end{array}$ & $\begin{array}{l}\text { STATE, BUSINESS } \\
\text { - INCUBATORS, } \\
\text { BUSINESS-ANGELS, } \\
\text { SEED-FUNDS }\end{array}$ & 100 \\
\hline Start - up stage & $\begin{array}{l}\text { MAKING OF PRODUCT, } \\
\text { CONDUCTION OF R\&D } \\
\text { WORKS, PRE-SALE MAR- } \\
\text { KETING, PREPARATION OF } \\
\text { MANUFACTURING }\end{array}$ & Venture funds & $30-40$ \\
\hline Expansionstage & $\begin{array}{c}\text { EXPANSION OF MANUFAC- } \\
\text { TURING, COMPREHENSIVE } \\
\text { MARKETING, RECEIVING } \\
\text { OF PROFIT } \\
\end{array}$ & $\begin{array}{c}\text { TRADITIONAL } \\
\text { SOURCES OF PROJ- } \\
\text { ECTS FINANCING }\end{array}$ & $10-20$ \\
\hline CAPITAL SUBSTITUTION & $\begin{array}{c}\text { TRANSFORMATION OF } \\
\text { INVESTMENT ASSETS } \\
\text { (CHANGE OF STRUCTURE, } \\
\text { PROPERTY RIGHT) } \\
\end{array}$ & $\begin{array}{c}\text { ASSETS OF SIDE IN- } \\
\text { VESTORS, PRIVATE } \\
\text { FUNDS }\end{array}$ & $1-2$ \\
\hline Ransom & $\begin{array}{l}\text { Application of forms: man- } \\
\text { agement buy - in(side inves- } \\
\text { tors), management buy - out } \\
\text { (private funds) }\end{array}$ & $\begin{array}{c}\text { ASSETS OF SIDE IN- } \\
\text { VESTORS, PRIVATE } \\
\text { FUNDS }\end{array}$ & $1-2$ \\
\hline
\end{tabular}

Withing the frames of construction of venture investment's financial mechanism a special attention must be paid to seed-stage. At this stage there is an absolute majority of developments conducted by scientific institutes, and from their support will be depended not only perspective of venture business itself, but also perspective of establishment of economically effective innovative system in the country. Stages of capital substitution and ransom in Russian practice can be united into restructurization stage. Within that stage shares of others investors and funds can be obtained, non-specialized departments can be saled, manufacturing assets can be enlarged and other activities referred to capitalization growth can be conducted. Withing financing of seed-stage during implementation of venture investment it will be actual to use assets of business-incubators, within, creation of regional agricultural technopolises.

\section{CONCLUSION}

At the modern stage of development of production forces and manufacturing relations it is necessary to say about their quality transformation within foamtion of model for country's innovative 
development. There are few evidences to this: firstly, development of Russia's economy at various hierarchical levels is located in dependance of investment attractiveness of its structural units. Innovative activity, as a predominant investment type, does not provoke any doubts. We can to observe a formation of world innovative model, and globalization and integration were preconditions to it.

Secondly, activization of small entrepreneurship development in our country, in various industries, including agricultural complex, is possible only through making of adequate regulatory-legal field with simultaneous removal of current obstacles and foramtion of necessary infrastructural elements at a regional level.

Thirdly, we have to solve an issue of accumulation of sufficiency for sources of investment resources purposed for small entrepreneurship, which in most cases are being sent to innovations.

Fourthly, creation of such infrastructural elements of investment-innovative support of small entrepreneuship as regional centers of transfer and regional venture funds will promote more fast pace of its development.

\section{Summary}

1. Results of anallitical research let us conclude, that at modern stage of small entrepreneurship development there is a necessity to activate its investment-innovative activity in purposes of achievement of competetive advantages in comparison with other countries - members of WTO. We can claim the fact, that amount of investment, including the one directed in small entrepreneurship innovations, is at low level, which create a threat for its further functioning.

2. By analyzing innovatiional subsystem as one of the most important components of economic system, we will register the presence of specific set of structural elements of low hierarchical level, which are interconnected. By other words, we register the presence of some investment-innovative infrastructure, which maintain producting of innovation and, which is especially actual, their transfer. Within this research a special interest was presented by such elements of investmentinnovative infrastructure, which are able to activate the development of small entrepre- neurship, as regional centers of agricultural technologies transfer and venture funds.

3. Centers of agricultural technologies transfer have to become a part of current innovative systems exist in regions by its restructuring. The main goal of regional center of agricultural technologies transfer is promotion of domestic and foreign innovative technologies with assistance of governmental structure. Other important element of investment-innovative infrastructure of economic mechanism has to be venture funds.

4. Innovative development of small entrepreneurship is highly difficult without support of public private partnership. At regional level principles of public private partnership can be implemented through establishment of venture funds in form of ended investment fund.

\section{ACKNOWLEDGEMENTS}

The article was published with the financial support from Ministry of Education and Science of the Russian Federation within the framework of state assignment to the project \#26.1511.2014K "Theory and methodology of managing innovational and investment processes in small business enterprises."

\section{REFERENCES}

1) Barras R.,1990.Interactive innovation in financial and business services: The vanguard of the service revolution // Research Policy, Vol.19, pp.215-237.

2) Black B.S., Gilson R.J.,1998.Venture Capital and the Structure of Capital Market: Banks versus Stock Market //Journal of Financial Economics.Vol.47.\# 3.P.243-277.

3) Markowitz, H., 1987. Mean-Variance Analysis in Portfolio Choice and Capital Markets / $\mathrm{H}$. Markowitz.- New York: Basil Blakwell, 275 p.

4) U.K. Leads European Venture-Capital Funding, but Russials Fastest Growing // TECHEUROPE. URL: http://blogs.wsj.com/ tech-europe/2013/01/29/u-k-leads-european-venture-capitalfunding-but-russia-is-fastest-growing/

5) Agarkov, S.A., 2005. Formation and implementation of innovative-investment policy of the country in development of region's economy.Moscow: RAGS, pp: 132. 
6) Mazloev, V.Z., 2009. Structural-institutional and functional specifications of agricultural integration. Economy of agricultural and processing enterprises, 4: 68-72.

7) Sandu, I.S., 2010. Modernization of organizational - economic mechanism of development of innovative annd labour processes in science annd agricultural production. Labout norm-fixing and payment in agriculture, 10: 28-37.

8) Ushachev, I.G., 2009. Strategic approaches to implementation of innovative models of agriculture. Collection of scientific work, devoted to 80th anniversary of VNIIESH. Modernization and innovative activity - strategic directions of agricultural complex development, 1: 3-14.

9) Sharp, U.F., G.J. Alexander and J. Baily, 2009.Investment. Infra-M, pp: 1028.

10) Abalkin, L.I., 2000. In search of new strategy. Moscow: Economics, pp: 799.

11) Doroshenko, Y.A.,Somina, I.V., Komissarov, S.A.,Doroshenko, S.Y., 2015. The Essence and Characteristics of Investment Processes in Small Innovative Enterprises.Asian Social Science. Vol. 11.N. 6. P. 185-191.

12) Doroshenko, Y.A. Somina, I.V. Komissarov,S. A., 2013. Sources of Financing and Innovative and Investment Activity of Small Enterprises.World Applied Sciences Journal.Vol. 25.N. 6. P. 975-982.

13) Kuznetsov, V.V., V.V. Garkaviy and A.N. Tarasov, 2005.Models of agricultural complex's economic development. Rostov-on-Don: VNIIEaN, pp: 544.

14) Melkumov, Y.S., 2000. Organization and planning of investments. Moscow: Infra-M, pp: 327.

15) Nechaev, V.I., E.I. Artemov and S.M. Reznichenko, 2007.Development of innovative processes in farm breeding.Krasnodar: Prosveschenie-Yug, pp: 277.

Paper sent to revision: 30.11.2015.

Paper ready for publication: 14.12.2015. 